\title{
INC's performance in Gujarat's reserved constituencies should be a lesson for future planning
}

--Shambhu Ghatak ${ }^{1}$

It was a Jo Jeeta Wohi Sikandar moment for the Indian National Congress (INC) in the reserved Scheduled Caste (SC) and Scheduled Tribe (ST) constituencies of Gujarat during the recent polls. A preliminary analysis of assembly election results pertaining to the reserved constituencies of the state shows that INC has outperformed the Bharatiya Janata Pary (BJP) on various aspects but BJP's rising power in the ST constituencies cannot be undermined.

It should be said at the outset that in a 182 seat contests, out of 77 seats that the INC secured in the 2017 assembly election of Gujarat, 15 came from the ST reserved constituencies and 5 came from the SC reserved constituencies. It means that roughly one-fourth (26 percent) of total INC seats (77 in nos.) were won from the reserved constituencies, thus, indicating why those constituencies mattered the most for the party.

Similarly, out of 99 seats that the BJP won during the assembly poll, 9 were from the ST reserved constituencies and 7 were won from the SC reserved constituencies. It shows that roughly 16.2 of total BJP seats (99 in nos.) were won from the reserved constituencies, which is lower than that of INC.

In the 2012 assembly election, 31.1 percent of total INC seats (61 in nos.) and 17.4 percent of total BJP seats (115 in nos.) were won from the reserved constituencies.

\section{A review of literature: 2017 Gujarat assembly election}

The Gujarat assembly election tracker which was prepared by the Lokniti team of Centre for the Study of Developing Societies (CSDS) in collaboration with ABP found that although the STs were in favour of the BJP in early August and October-end in 2017, they came back with the INC in November-end. ${ }^{2}$ That tracker shows that the vote share in favour of the BJP (among the STs) exceeded that of the INC by 21 percentage points in early August and 18 percentage points in October-end but in November-end vote share in favour of the INC (among the tribals) exceeded that of the BJP by 18 percentage points.

According to that Lokniti-ABP tracker, INC's alliance with the Bhartiya Tribal Party (BTP) helped it in getting support at a later stage from STs. It should be added here that the survey for that tracker was canvassed for the entire state and was not just confined to the reserved ST constituencies.

The same tracker prepared by the Lokniti team suggests that SCs (i.e. dalits) were in favour of INC vis-à-vis the BJP in all the three time-points. The tracker shows that the vote share in favour

\footnotetext{
${ }^{1}$ Shambhu Ghatak is Senior Associate Fellow with Common Cause and is coordinator of Inclusive Media for Change Project, www.im4change.org. His email ID is: shambhucommon@gmail.com . Views expressed are personal.

${ }^{2}$ Lokniti-CSDS-ABP News Gujarat Pre-Election Tracker, Round 3, December 4, 2017, https://goo.gl/DSfwDY
} 
of the INC (among the SCs) exceeded that of the BJP by 14 percentage points in early August, 8 percentage points in October-end and 18 percentage points in November-end.

Souradeep Banerjee and Shashwat Dhar (2017) in their article entitled Victory sans Grandeur: Gujarat Assembly Election 2017 mention that despite being in power at the state-level for a long time, BJP could manage to increase its vote share from 48.0 percent in 2012 to 49.1 percent in 2017. ${ }^{3}$ However, the BJP could not achieve its objective of Congress-mukt Bharat (an India without the Congress). The authors show that INC's vote share increased from 38.9 percent in 2012 to 41.4 percent in 2017. Its overall seat tally also went up from 61 to 77 between 2012 and 2017.

Based on the Lokniti-CSDS Gujarat post-poll survey 2017 that was conducted for the entire state (and not just in SC and ST reserved constituencies), Banerjee and Dhar (2017) show that among the SCs, 53 percent voted for INC whereas 39 percent voted for BJP in 2017. But in 2012, among the SCs 67 voted for INC and 23 percent voted for BJP. The authors point out that among the Bhils -- an ST community, 38 percent voted for INC in 2017, which was 49 in 2012. However, 38 percent Bhils voted for BJP in 2012, which fell marginally to 36 percent in 2017. Similarly, among the other STs 46 percent voted for INC in 2017, which was 45 in 2012. However, 31 percent other STs voted for BJP in 2012, which increased to 47 percent in 2017.

Banerjee and Dhar (2017) say that gains made by the INC among the Patels and lower Other Backward Classes (OBCs) were offset by the decline of its support base among the Rajputs, SCs and STs. Although INC made impressive gains among the Leuva Patels, BJP retained majority share of the Patel vote in 2017.

Due to the presence of the Rashtriya Swyamsevak Sangh (RSS) in the ST and SC pockets of the state, a considerable chunk of the ST and SC voters shifted towards the BJP in 2017, state Banerjee and Dhar (2017) in their article. Hence, it can be said that unlike what was expected, INC's alliance with dalit leader Jignesh Mevani did not yield major political gains.

Ghanshyam Shah (2018) in his article entitled BJP's Sixth Victory in Gujarat: A Puzzle state that in spite of the dalit agitation in Una and leadership of Jignesh Mevani, the INC could not get a large share of SC votes in 2017. ${ }^{4}$ In fact, one-fifth of SC votes went to Bahujan Samaj Party (BSP), NOTA (None of the Above), and independent candidates. Similarly, the INC was unable to improve its vote share as compared the previous elections among the STs.

The BJP could not make much impact in INC's vote share in 2017 despite Vanbandhu Kalyan Yojana, skill development institutions, and other infrastructure development, mentions Shah (2018). The Gujarat model failed to improve the employment situation for the educated middleclass tribal youth and did not reduce overall poverty level.

\footnotetext{
3 Banerjee, Souradeep and Dhar, Shashwat (2017): Victory sans Grandeur: Gujarat Assembly Election 2017, Economic and Political Weekly, 23 December, Vol. 52, Issue No. 51, https://goo.gl/8rayVS

${ }^{4}$ Shah, Ghanshyam (2018): A Puzzle: BJP's Sixth Victory in Gujarat, Economic and Political Weekly, 13 January, Vol. 53, Issue No. 2, https://goo.gl/bixHbp
} 
Although Mevani was active in his constituency (viz. Vadgam) and won but it is difficult to assess his influence on SC voters in other constituencies, says Shah (2018).

An opinion piece by journalist Vinod Sharma, which was published in the Hindustan Times (dated 7 November, 2018) prior to the state's assembly election, advises that instead of depending too much on the tripartite alliance of Patidar leader Hardik Patel, dalit activist Jignesh Mevani and OBC representative Alpesh Thakor, the INC should project faces from among STs and SCs. ${ }^{5}$

A Times of India opinion piece by Sanjeev Singh (2017) written before the assembly election also says that the INC's sole focus to get Patidar votes could provide an opportunity for BJP to fine-tune its strategy to gain tribal votes. ${ }^{6}$

\section{A review of literature: Past trends in assembly elections of Gujarat}

It could be discerned from the chart-1(a) that in the last 7 assembly polls in Gujarat since 1990, INC's vote share in seats contested crossed 40 percent for the first time in 2012 and for the second time in 2017. Since 2002, BJP's vote share in seats contested lingered around 49 percent. Please take a look at chart-1(a).

The number of seats won as a proportion of seats contested was greater than 60 percent for the BJP in the assembly polls of 1995, 1998, 2002, 2007 and 2012. In contrast, the number of seats won as a proportion of seats contested was more than 40 percent for INC in the assembly elections of 2017.

Chart 1(a): Vote share (\%) in seats contested and seats won as a proportion of seats contested $(\%)$ in various assembly elections in Gujarat

\footnotetext{
${ }^{5}$ Sharma, Vinod (2017): About time Congress projected tribal faces in Gujarat, Hindustan Times, 7 November, https://goo.gl/mXxCv3

${ }^{6}$ Singh, Sanjeev (2017): Why tribal votes could spring a surprise in Gujarat elections, The Times of India blog, 28 November, https://goo.gl/vAVz8T
} 


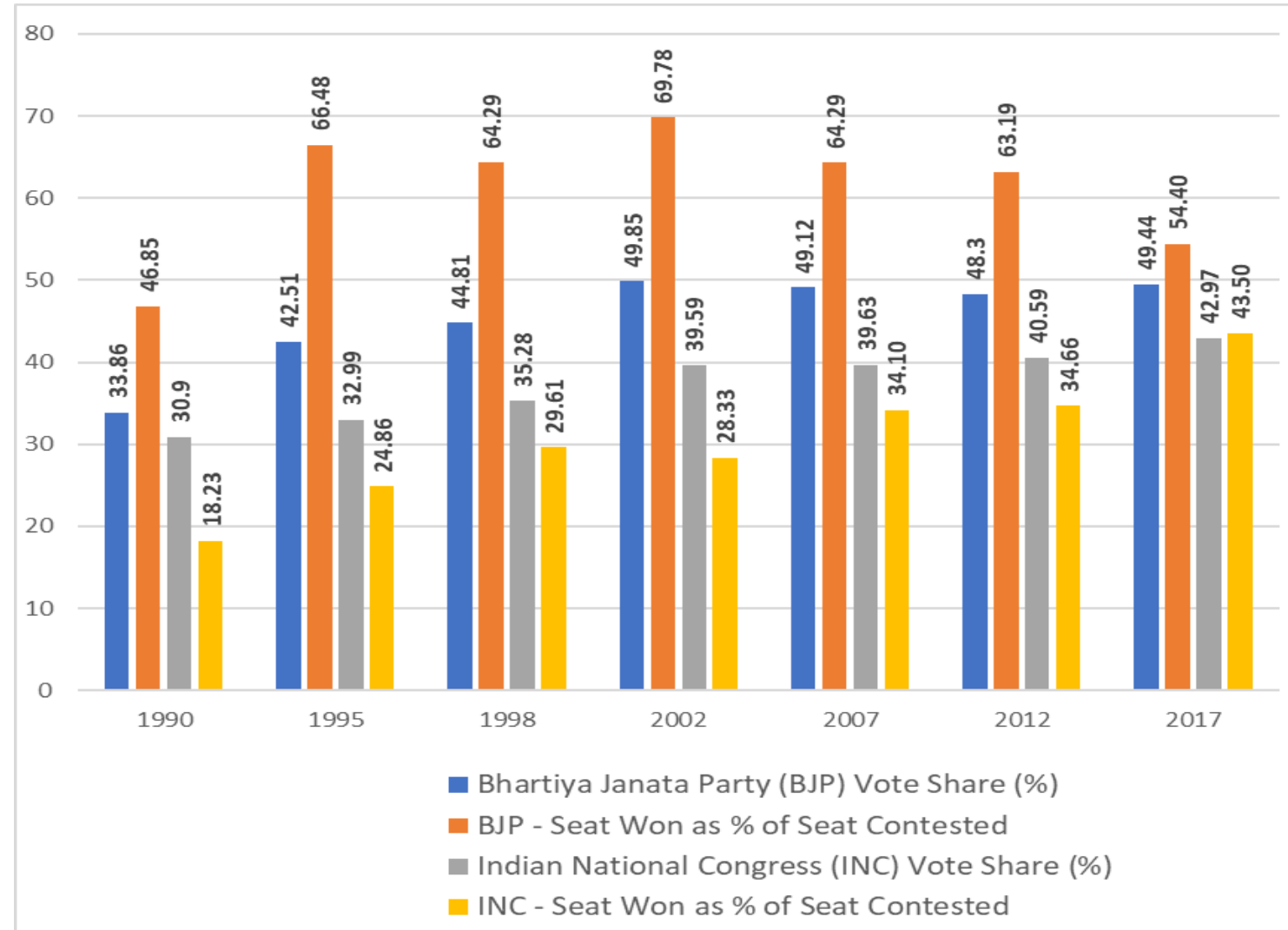

Source: Performance of Political Parties, Gujarat General Legislative Election 2017, https://bit.ly/2JZYTNr (accessed in November, 2018)

Statistical Report on General Election - 2012 to the Legislative Assembly of Gujarat, https://bit.ly/2T9Xnwb (accessed in November, 2018)

Statistical Report on General Election - 2007 to the Legislative Assembly of Gujarat, https://bit.ly/2B2fNIw (accessed in November, 2018)

Statistical Report on General Election - 2002 to the Legislative Assembly of Gujarat, https://bit.ly/2DBIM8o (accessed in November, 2018)

Statistical Report on General Election - 1998 to the Legislative Assembly of Gujarat, https://bit.ly/2DhgUpa (accessed in November, 2018)

Statistical Report on General Election - 1995 to the Legislative Assembly of Gujarat, https://bit.ly/2B47dZF (accessed in November, 2018)

Statistical Report on General Election - 1990 to the Legislative Assembly of Gujarat, https://bit.ly/2T7M5bW (accessed in November, 2018) 
From chart-1(b), one gets that for the first time since 1995 the total number of seats won by BJP in different assembly elections of Gujarat came down below 100 in 2017. In fact, between 1990 and 2017 BJP won the maximum number of seats (viz. 127 in numbers) in the assembly polls of 2002. In contrast, the total number of seats won by INC in various assembly elections of Gujarat has more than doubled from 33 in 1990 to 77 in 2017, although the number of seats won by the party dipped slightly to 51 in 2002 from 53 in 1998. Clearly, the Gujarat pogrom in 2002 was a watershed in Indian politics.

\section{Chart 1(b): Number of seats won by BJP and INC in various assembly elections in Gujarat}

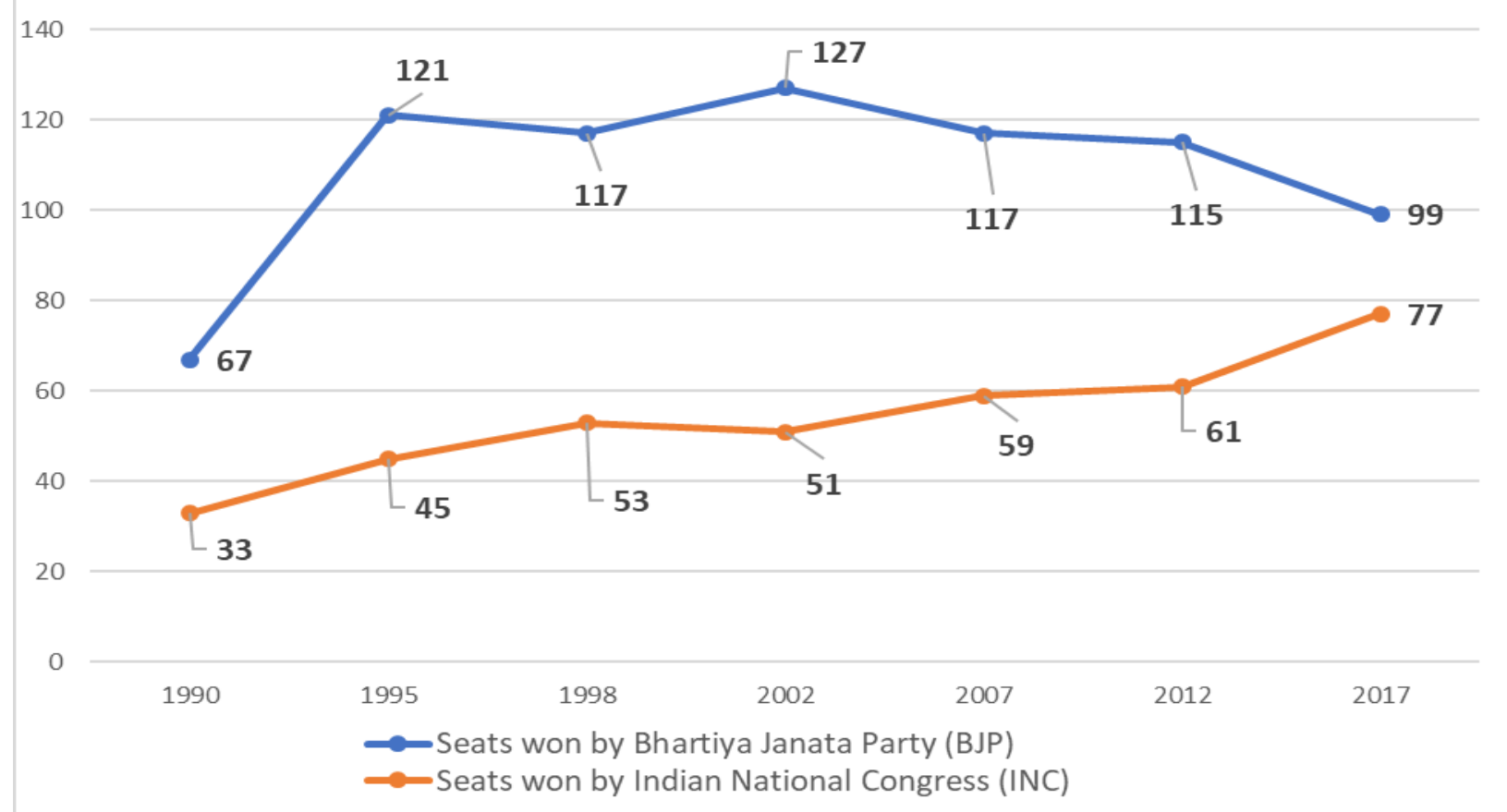

Source: Same as in chart-1(a)

Since 1990, the total number of seats won by INC during assembly elections in the ST reserved constituencies surpassed the total number of seats won by BJP, except in the years 1995 and 2002. The total number of seats won by INC during assembly elections in the SC constituencies was always lesser than the total number of seats won by BJP since 1990. However, during the 2017 assembly polls, BJP (7) was marginally ahead of INC (5) in terms of winning SC reserved seats. Please check table-1(a) for details.

It needs to be added here that as per the Delimitation of Parliamentary and Assembly Constituencies Order (2008), there was no change made in the total number of SC (2 in numbers) and ST (4 in numbers) reserved seats in Gujarat for the Lok Sabha. However, based on the same 
Order, the total number of ST reserved seats in Gujarat for the Vidhan Sabha was raised from 26 to 27. There was no change made in the total number of SC (13 in numbers) reserved seats for the Vidhan Sabha. ${ }^{7}$

Table 1(a): Seats won by various political parties during Gujarat assembly polls in SC and ST constituencies

\begin{tabular}{|c|c|c|c|c|c|c|c|c|c|c|c|c|c|c|}
\hline \multirow{2}{*}{$\begin{array}{l}\text { Political } \\
\text { Parties }\end{array}$} & \multicolumn{2}{|c|}{1990} & \multicolumn{2}{|c|}{1995} & \multicolumn{2}{|c|}{1998} & \multicolumn{2}{|c|}{2002} & \multicolumn{2}{|c|}{2007} & \multicolumn{2}{|c|}{2012} & \multicolumn{2}{|c|}{2017} \\
\hline & $\begin{array}{c}\text { SC } \\
\text { seats } \\
\text { won } \\
\end{array}$ & $\begin{array}{c}\text { ST } \\
\text { seats } \\
\text { won } \\
\end{array}$ & $\begin{array}{c}\text { SC } \\
\text { seats } \\
\text { won } \\
\end{array}$ & $\begin{array}{c}\text { ST } \\
\text { seats } \\
\text { won } \\
\end{array}$ & $\begin{array}{c}\text { SC } \\
\text { seats } \\
\text { won } \\
\end{array}$ & $\begin{array}{c}\text { ST } \\
\text { seats } \\
\text { won } \\
\end{array}$ & $\begin{array}{c}\text { SC } \\
\text { seats } \\
\text { won } \\
\end{array}$ & $\begin{array}{c}\text { ST } \\
\text { seats } \\
\text { won } \\
\end{array}$ & $\begin{array}{c}\text { SC } \\
\text { seats } \\
\text { won } \\
\end{array}$ & $\begin{array}{c}\text { ST } \\
\text { seats } \\
\text { won } \\
\end{array}$ & $\begin{array}{c}\text { SC } \\
\text { seats } \\
\text { won } \\
\end{array}$ & $\begin{array}{c}\text { ST } \\
\text { seats } \\
\text { won } \\
\end{array}$ & $\begin{array}{c}\text { SC } \\
\text { seats } \\
\text { won } \\
\end{array}$ & $\begin{array}{c}\text { ST seats } \\
\text { won }\end{array}$ \\
\hline $\begin{array}{l}\text { Bhartiya } \\
\text { Janata Party } \\
\text { (BJP) }\end{array}$ & 6 & 6 & 10 & 14 & 8 & 8 & 9 & 13 & 11 & 11 & 10 & 10 & 7 & 9 \\
\hline $\begin{array}{l}\text { Indian } \\
\text { National } \\
\text { Congress } \\
\text { (INC) }\end{array}$ & 1 & 7 & 3 & 8 & 5 & 15 & 4 & 11 & 2 & 14 & 3 & 16 & 5 & 15 \\
\hline $\begin{array}{l}\text { Janata Dal } \\
\text { (JD) }\end{array}$ & 6 & 11 & & & & 3 & & & & & & & & \\
\hline Independent & & 2 & & 4 & & & & & & & & & 1 & 1 \\
\hline $\begin{array}{l}\text { Janata Dal } \\
\text { United (JD- } \\
\text { U) }\end{array}$ & & & & & & & & 2 & & 1 & & 1 & & \\
\hline $\begin{array}{l}\text { Bhartiya } \\
\text { Tribal Party } \\
\text { (BTP) }\end{array}$ & & & & & & & & & & & & & & 2 \\
\hline Total seats & 13 & 26 & 13 & 26 & 13 & 26 & 13 & 26 & 13 & 26 & 13 & 27 & 13 & 27 \\
\hline
\end{tabular}

Source: Same as in chart-1(a)

In the past, the Patidars of Saurashtra used to be strong supporters of INC since they had benefitted from the land reforms. However, seeing their class interest getting affected by INC's effort to win over all social groups and espousal of pro-poor policies, the Patidars shifted their loyalty to Swatantra Party - a party that provided platform to landed (ex-zamindars) Rajputs and Patidars. After the demise of Swatantra Party, the landed class gradually shifted its support first to the Janata Party and then to the Jana Sangh. Following the adoption of KHAM (Kshatriya, Harijan, Adivasi and Muslim) alliance strategy in the late 1970s by INC coupled with reservation policy for Other Backward Classes (OBCs), SCs and STs, BJP was able to garner support of upper and middle castes. Although Patidars are considered to be BJP's backbone among the upper castes, their support would not help BJP to win elections. So, getting support of the

\footnotetext{
7 Delimitation of Parliamentary and Assembly Constituencies Order, 2008, Election Commission of India, https://bit.ly/2OMHrfY (accessed in November, 2018)
} 
deprived communities, who are in majority, is a prerequisite to not just win elections but also to defeat 'others' viz. Muslims and Christians (Shah, 2004, p. 165). ${ }^{8}$

After winning the trust of urban middle class through riots, agitations and coalition politics, BJP replicated the INC strategy of KHAM, however, with a difference. BJP isolated Muslims as 'others' from the deprived communities in the state. Poor Muslims were excluded from the state's welfare programmes. Hegemony of the upper castes was not disturbed and social reforms and abolition of untouchability were not given attention by the Sangh Parivar. BJP was, however, unable to harmonize conflicting interests of the OBCs and Patidars. As a result, OBC support for INC and BJP during various elections in the state fluctuated. The Sangh Parivar, however, was successful to mobilize the OBCs in Central Gujarat against the Muslims in riots, 'rath yatras' and also during the 2002 assembly polls (Shah, 2004, p. 165-166).

Based on various reports of the National Election Study prepared by the Lokniti team of Centre for the Study of Developing Societies (CSDS), Ghanshyam Shah (2014) says that although SC voters in general (viz. in all constituencies of Gujarat, and not just in the reserved ones) have traditionally remained loyal to the INC in various Lok Sabha and assembly elections, their share (among total votes casted in favour of INC by various castes/ communities) fell from 63 percent to 46 percent between 2009 and 2014. SCs constitute seven percent of the state's population and none of the assembly constituencies has more than 15 percent SC voters (p. 272-273). ${ }^{9}$

SC voters, who moved away from INC, shifted their support to Aam Aadmi Party (AAP) or independent candidates in the 2014 Parliamentary elections. Prior to the 2014 Lok Sabha election, the Modi-led state government of Gujarat failed to take effective action against atrocities committed against the dalits including the practice of untouchability in rural areas (Shah, 2014, p. 273-274).

Although BJP had tried to woo SC voters by co-opting a few dalit writers and political aspirants apart from celebrating Dr. Ambedkar's birthday as 'samrasata' (harmony) day, dalit activists questioned the party on ideological grounds. In 2013, dalits of Gujarat in large numbers celebrated Dr. Ambedkar's birthday as 'samanta' day viz. 'equality' days as opposed to 'samrasta' day (Shah, 2014, p. 273).

STs, who constitute nearly 14 percent of the state's population, largely reside in the most backward blocks. A small middle-class of tribals, which emerged over the years, follow the aspirations and the world view of non-tribal upper castes (Shah, 2014, p. 274).

The radical and pro-poor faction of INC, which struggled for land rights of the tribals, as opposed to the apolitical Gandhian moralists, mobilized the ST voters in favour of the party. Although Jinabhai Darjee emerged as the leader of ST voters since the late 1960s and Amarsinh Chaudhari - a new tribal leader belonging to INC — became the chief minister between 1985 and 1990, INC's support base among the ST voters started dwindling in the late 1980s. INC,

\footnotetext{
8 Shah, Ghanshyam (2004): Chapter 6: Gujarat after Godhra, in the book entitled 'India's 2004 Elections: Grassroots and National Perspectives' edited by Ramashray Roy and Paul Wallace, Sage Publications

9 Shah, Ghanshyam (2014): Chapter 11: Mega Marketing and Management: Gujarat's 2014 Elections, in the book entitled 'India's 2014 Elections: A Modi-led BJP Sweep' edited by Paul Wallace, Sage Publications
} 
which won all the 26 reserved ST seats in 1985, lost 19 seats in the 1990 assembly polls. The factors responsible for decline in support of ST voters for INC are: a. Growing factional fights within the INC; b. Tribal leader Jinabhai Darjee was sidelined within the party for his pro-poor views due to which he left active politics in the mid-1990s; c. Many INC leaders left the party and joined the Janata Dal under Chimanbhai Patel's leadership; d. Gandhian constructive institutions, which were once active, got defunct; and e. Advani's 'rath yatra' through the tribal belt in the late 1980s mobilized the ST voters against the INC (Shah, 2004, p. 169-170).

By organizing various 'yatras' (rallies/ marches) in the state like the 'nyaya yatra' (pilgrimage for justice) in 1985-86, forming Harijan and Vanvasi (Adivasi/ tribal) cells and floating organisations like Samajik Sam-Rasata Manch (SSM) or 'Social Assimilation Platform', BJP and the Sangh Parivar since the 1980s had tried to rope in the support of SCs and STs in the state of Gujarat. This was done without challenging the existing social hierarchy and practices like untouchability. Every effort was made by the Sangh Parivar to showcase Dr. BR Ambedkar as a Hindu and his ideas as pro-Hindutva (Shah, 2004, p. 167). Hinduization of tribals became the focus of Sangh Parivar backed institutions like Vanvasi Kalyan Ashram, Ekal Vidyalaya, Sewa Bharati, Vivekananda Kendra, Bharat Kalyan, and Pratishthan Friends of Tribal Society (Shah, 2004, p. 170).

Traditionally, INC enjoyed the support of ST voters on account of the widespread institutional network of Gandhians, who were active in the fields of education and social reforms. However, Hindutva forces entered the arena in 1960s and broadened their support base among the STs with the Ram Janambhumi movement. Due to the growing dissatisfaction against INC's rule coupled with the marginalization of pro-tribal leaders in the party, Congress' support base among the ST voters dwindled. The entry of new leadership was blocked by the tribal leaders of INC. As a result, BJP won six out of the 26 reserved ST seats in 1990. INC won 7 seats in that assembly elections and majority of the seats went to others viz. Janata Dal (11) and independent candidates (2) (Shah, 2014, p. 274).

BJP got victory in 14 ST reserved seats with 36 percent vote share in the 1995 elections - 11 out of 16 seats for BJP came from South Gujarat. Although INC won 15 seats with 44 percent vote share in the 1998 elections, BJP could manage winning only 8 ST reserved seats. Hindutva forces including the Vishva Hindu Parishad (VHP) and Bajrang Dal mobilized tribals against Christian missionaries in the Dangs during the late 1990s. In the post-Godhra riots, ST youths were mobilized against the Muslims (particularly traders and contractors) in central Gujarat viz. Dahod, Godhra and Vadodara districts. Although in 2002 BJP won assembly seats in Vadodara, Dahod and Panchmahal districts, it could manage to win only13 out of 26 ST reserved seats. INC won 11 seats in the 2002 elections (Shah, 2004, p. 171-172).

During the 2002 anti-Muslim carnage, Hindutva forces in the state mobilized tribals, after which BJP (13 out of 26) captured majority of the ST reserved seats in 2002. However, BJP could not sustain its electoral victory in the next assembly elections in the ST reserved seats. Instead of relying merely on mobilization around culture, construction of temples as pilgrimage/ tourist places was incorporated with a development agenda as part of BJP's Hinduization mission (Shah, 2014, p. 274). 
Although the Vanbandhu Kalyan Yojana (VKY) was launched for the period of 2007-2012 with much fanfare, the programme could make little impact on the lives of tribal people. The VKY lacked integration and forward and backward linkages. In its approach and method of implementation, the VKY resembled the Integrated Rural Development Programme viz. IRDP (Shah, 2014, p. 274-275).

The Gujarat state government's effort to impart skill among tribal youths through Industrial Training Institutes (ITIs), Kaushalya Vardhan Kendra (skill development centres) and Kaushalya Raths (skill vans) apart from enforcement of the Forest Rights Act helped BJP to improve its vote share among the ST voters in the 2014 assembly polls. However, it made little dent in INC votes since anti-Congress votes of other parties or independent candidates went to BJP (Shah, 2014, p. 275).

Table 1(b): Trend of party preference by various castes/ communities

\begin{tabular}{|l|c|c|c|c|c|c|}
\hline & \multicolumn{6}{|c|}{ Bhartiya Janata Party (BJP) } \\
\hline Caste/ Community & $\mathbf{1 9 9 5}$ & $\mathbf{1 9 9 6}$ & $\mathbf{1 9 9 8}$ & $\mathbf{1 9 9 9}$ & $\mathbf{2 0 0 2}$ & $\mathbf{2 0 0 4}$ \\
\hline Upper castes & 67 & 76 & 77 & 77 & 79 & 67 \\
\hline OBCs & 38 & 65 & 57 & 38 & 59 & 40 \\
\hline SCs & 17 & 61 & 47 & 33 & 27 & 24 \\
\hline STs & 29 & 34 & 43 & 33 & 34 & 48 \\
\hline Muslims & 7 & 33 & 38 & 10 & 10 & 20 \\
\hline & \multicolumn{7}{|c|}{ Indian National Congress (INC) } \\
\hline Caste/ Community & $\mathbf{1 9 9 5}$ & $\mathbf{1 9 9 6}$ & $\mathbf{1 9 9 8}$ & $\mathbf{1 9 9 9}$ & $\mathbf{2 0 0 2}$ & $\mathbf{2 0 0 4}$ \\
\hline Upper castes & 20 & 18 & 13 & 16 & 16 & 26 \\
\hline OBCs & 38 & 30 & 28 & 61 & 38 & 55 \\
\hline SCs & 61 & 35 & 45 & 64 & 67 & 67 \\
\hline STs & 59 & 55 & 46 & 67 & 49 & 46 \\
\hline Muslims & 47 & 68 & 62 & 90 & 69 & 60 \\
\hline
\end{tabular}

Source: Chapter 6: Gujarat after Godhra, in the book entitled 'India's 2004 Elections: Grassroots and National Perspectives' edited by Ramashray Roy and Paul Wallace, Sage Publications, page no. 173; The election survey of 1996 was conducted by Centre for Social Studies, Surat and confined to rural areas. The other surveys were conducted by CSDS, Delhi

Notes: 1996 N=484; $1998 N=340 ; 1999 N=381 ; 2002 N=1853 ; 2004 N=914 ;$ (N=number of respondents)

After the 1998 elections, INC was able to slowly garner the support of OBCs, SCs and STs, as is shown by table-1(b), which is reproduced here from the chapter entitled Gujarat after Godhra written by Ghanshyam Shah (2004) in the book edited by Ramashray Roy and Paul Wallace (2004). Although BJP was able to gain support among the ST voters, its reversal started since the 1999 elections. INC also gained the support of SC and OBC voters following the 1998 elections. 


\section{Chances of winning and INC's strategy in ST seats}

The 27 ST reserved constituencies, which have been studied by me pertaining to the 2012 and 2017 assembly polls, are: Bhiloda (Sabarkantha), Chhota Udaipur (Vadodara), Dahod (Dahod), Dangs (Dangs), Danta (Banaskantha), Dediapada (Narmada), Dharampur (Valsad), Fatepura (Dahod), Gandevi (Navsari), Garbada (Dahod), Jetpur (Vadodara), Jhagadiya (Bharuch), Jhalod (Dahod), Kaprada (Valsad), Khedbrahma (Sabarkantha), Limkheda (Dahod), Mahuva (Surat), Mandvi (Surat), Mangrol (Surat), Morva Hadaf (Panchmahal), Nandod (Narmada), Nizar (Surat), Sankheda (Vadodara), Santrampur (Panchmahals), Umbergaon (Valsad), Vansda (Navsari) and Vyara (Tapi).

Although the INC fielded candidates in all the 27 ST constituencies in 2012, it won only in 16 seats. It means that the probability of winning in ST constituencies was 59.3 percent for the party. The probability of winning for the BJP in the ST constituencies in that year was much lesser i.e. around 37 percent. Please consult table-2(a) for further details.

Table 2(a): Performance of BJP and INC in the 27 ST reserved constituencies during 2012 and 2017 Gujarat assembly elections

\begin{tabular}{|c|c|c|c|c|c|c|c|}
\hline \multicolumn{4}{|c|}{2012} & \multicolumn{4}{|c|}{2017} \\
\hline $\begin{array}{c}\text { Number of seats } \\
\text { contested }\end{array}$ & \multicolumn{2}{|l|}{ Number of seats won } & \multicolumn{2}{c|}{$\begin{array}{c}\text { Number of seats } \\
\text { contested }\end{array}$} & \multicolumn{2}{c|}{$\begin{array}{c}\text { Number of seats } \\
\text { won }\end{array}$} \\
\hline BJP & INC & BJP & INC & BJP & INC & BJP & INC \\
\hline 27 & 27 & 10 & 16 & 27 & 24 & 9 & 15 \\
\hline
\end{tabular}

Source: Data pertaining to 2012 taken from Statistical Report on General Election, 2012 to the Legislative Assembly of Gujarat, Election Commission of India, New Delhi, http://eci.nic.in/eci_main/StatisticalReports/SE_2012/Reports_Index\%20Card_ECIApplication_ GujaratState_CEO.pdf(accessed in January, 2018)

Data pertaining to 2017 taken from the Election Commission website, http://eciresults.nic.in/ (accessed in January, 2018), http://eci.nic.in/eci_main1/statistical reportGJ.aspx (accessed in April, 2018)

The INC contested from 24 reserved ST constituencies in the recently held assembly polls, in which it was victorious in 15. It means that the probability of winning in ST constituencies went up from 59.3 in 2012 to 62.5 percent for INC. On the contrary, BJP's chances of winning in the ST constituencies dipped further from 37 percent to 33.3 percent between 2012 and 2017. It won only in 9 seats after contesting from all the 27 ST constituencies.

In 2017, the INC did not field its candidates in 3 ST reserved constituencies namely, Dediapada (Narmada), Jhagadiya (Bharuch) and Morva Hadaf (Panchmahal). The INC formed a pre-poll alliance with Chhotubhai Amarsinh Vasava's newly formed Bhartiya Tribal Party (BTP), which 
won 2 seats from Dediapada and Jhagadiya. One should know that Vasava was expelled from the Janata Dal (United) when he voted in favour of INC veteran Ahmed Patel during the Rajya Sabha elections in August 2017. ${ }^{10}$

By joining hands with INC in 2017, BTP won the Dediapara and Jhagadiya seats, which were earlier occupied by BJP and JD (U), respectively. It may be noted that although Chhotubhai Amarsinh Vasava of BTP won (and got 1,13,854 votes) in 2017 (he also won from the same constituency in 2012) from Jhagadiya, another candidate named Chhotubhai A Vasava from JD (U) contested from that seat but got only 5,055 votes (which was much lesser than the total None of the Above-NOTA votes of 5,364 casted).

Although BTP's Maheshbhai Chhotubhai Vasava won from Dediapara in 2017, a candidate named Rajendrasinh Gumansinh Deshmukh from the Indian New Congress Party (a lesser known party) also contested the election but became the second runner-up. Motilal Puniabhai Vasava of BJP, who became the runner-up, had won the Dediapara seat in 2012. It may be noted that Maheshbhai Chhotubhai Vasava fought with a JD (U) ticket in 2012 but came third that time.

Alpeshbhai Tersingbhai Damor (8,246 votes) of BTP came third from Morva Hadaf constituency, and the seat went to an independent candidate Bhupendrasinh Vechatbhai Khant (58,513 votes) in 2017. BJP's Vikramsinh Ramsinh Dindor (54,147 votes) became the runner-up.

\section{Vote share and victory margins in ST constituencies}

On an average, a winning candidate from INC got a vote share of 51.5 percent in 2012, which declined marginally to 50.4 percent in 2017. In contrast, a victorious candidate from BJP got an average vote share of 47.9 percent in 2012, which went up to 53.6 percent in 2017 . Please check table-2(b) for further details.

10 Deepalakshmi, K (2017): Bharatiya Tribal Party opens account in Gujarat, The Hindu, 18 December, https://goo.gl/tnmVqW 
Table 2(b): Performance of BJP and INC candidates in terms of vote share and victory margin in the ST reserved seats

\begin{tabular}{|c|c|c|c|c|c|c|c|}
\hline \multicolumn{4}{|c|}{2012} & \multicolumn{4}{|c|}{2017} \\
\hline \multicolumn{2}{|c|}{$\begin{array}{l}\text { Average vote share of } \\
\text { winning candidates }\end{array}$} & \multicolumn{2}{|c|}{$\begin{array}{c}\text { Average vote share } \\
\text { of runner-up } \\
\text { candidates }\end{array}$} & \multicolumn{2}{|c|}{$\begin{array}{c}\text { Average vote share } \\
\text { of winning } \\
\text { candidates }\end{array}$} & \multicolumn{2}{|c|}{$\begin{array}{c}\text { Average vote share } \\
\text { of runner-up } \\
\text { candidates }\end{array}$} \\
\hline BJP & INC & BJP & INC & BJP & INC & BJP & INC \\
\hline 47.9 & 51.5 & 35.8 & 37.4 & 53.6 & 50.4 & 40.8 & 39.7 \\
\hline \multicolumn{2}{|c|}{$\begin{array}{c}\text { Average victory } \\
\text { margin of winning } \\
\text { candidate }\end{array}$} & \multicolumn{2}{|c|}{$\begin{array}{c}\text { Number of } \\
\text { constituencies where } \\
\text { candidate won by a } \\
\text { margin of }<\text { or }= \\
3000 \text { valid votes }\end{array}$} & \multicolumn{2}{|c|}{$\begin{array}{c}\text { Average victory } \\
\text { margin of winning } \\
\text { candidate }\end{array}$} & \multicolumn{2}{|c|}{$\begin{array}{c}\text { Number of } \\
\text { constituencies where } \\
\text { candidate won by a } \\
\text { margin of }<\text { or }= \\
\mathbf{3 0 0 0} \text { valid votes }\end{array}$} \\
\hline $\begin{array}{c}\text { BJP } \\
\text { (C.V.) }\end{array}$ & $\begin{array}{c}\text { INC } \\
\text { (C.V.) }\end{array}$ & BJP & INC & $\begin{array}{c}\text { BJP } \\
\text { (C.V.) }\end{array}$ & $\begin{array}{c}\text { INC } \\
\text { (C.V.) }\end{array}$ & BJP & INC \\
\hline $\begin{array}{l}15134.3 \\
(67.7 \%)\end{array}$ & $\begin{array}{c}22796 \\
(64.0 \%)\end{array}$ & 1 & 3 & $\begin{array}{c}23303 \\
(81.9 \%)\end{array}$ & $\begin{array}{l}15557.7 \\
(85.9 \%)\end{array}$ & 1 & 3 \\
\hline
\end{tabular}

Note: C.V. stands for coefficient of variation, which is the ratio of the standard deviation to arithmetic mean multiplied by 100

Source: Same as in table-2(a)

A victorious candidate from the INC on an average won by margin of 22,796 votes against the runner-up in 2012 but this margin fell to 15,557.7 votes in 2017. On the other hand, a winning candidate from the BJP won by an average margin of 15,134.3 votes in 2012, which went up to 23,303 in 2017.

The volatility or variability in the victory margin (as measured by coefficient of variation) of INC candidates has risen from 64.0 percent to 85.9 percent between 2012 and 2017. Similarly, the volatility in the victory margin of BJP candidates has gone up from 67.7 percent to 81.9 percent between 2012 and 2017.

In 2012, one candidate from the BJP and 3 candidates from the INC won by a margin of less than 3,000 votes against the runner-up. The same trend continued in 2017.

In the Dediapada assembly constituency, Motilal Puniabhai Vasava of BJP won against INC's Amarsinh Ramsinh Vasava by 2,555 votes in 2012. The sitting MLA of BJP, however, was defeated by BTP's Maheshbhai Chhotubhai Vasava by 21,751 votes in 2017 assembly elections.

In 2012, INC's Mohansinh Chhotubhai Rathwa defeated Gulsingbhai Ranglabhai Rathwa of BJP by 2,305 votes in the Chhota Udaipur constituency. The sitting MLA of INC at the same 
constituency defeated BJP's Jashubhai Bhilubhai Rathwa by 1,093 votes in 2017. The total number of votes in favour of 'None of the above' (NOTA) was 5,870 in that constituency.

In the Dangs assembly seat, INC's Mangalbhai Gangajibhai Gavit won against Vijaybhai Rameshbhai Patel of BJP by 2,422 votes and 768 votes during 2012 and 2017, respectively. In 2017, the total number of votes in favour of NOTA was 2,184 in Dangs.

In the 2012 assembly polls, Dhirubhai Chunilal Bhil of INC defeated BJP's Abhesinh Motibhai Tadvi by 1,452 votes in the Sankheda constituency.

In the 2017 assembly polls, Rameshbhai Bhurabhai Katara of BJP defeated INC's Raghubhai Ditabhai Machhar by 2,711 votes in Fatepura (Dahod district). The total number of NOTA votes was 4,573 in this constituency.

During the 2017 elections, Jitubhai Harjibhai Chaudhari of INC won against BJP's Madhubhai Bapubhai Raut by a wafer-thin margin of 170 votes in Kaprada (Valsad district). The total number of NOTA votes was 3,868 in this constituency.

\section{Anti-incumbency factor in ST seats}

The BJP snatched 3 ST reserved seats from the INC in 2017 due to anti-incumbency factor viz. Dharampur, Sankheda and Santrampur. Similarly, the INC candidates won in 3 assembly seats in 2017, which were previously occupied by BJP viz. Jetpur, Nandod and Nizar. Please refer to table-2(c).

In the 3 constituencies of Dharampur, Sankheda and Santrampur, the average victory margin of the BJP candidates against the nearest INC rival was 13,839.7 votes (but lesser than the average victory margin of BJP candidates who won viz. 23,303 votes), and the average vote share of BJP candidates in those seats was 50.6 percent (but lesser than the average vote share of winning BJP candidate viz. 53.6 percent).

Table 2(c): Number of ST reserved constituencies where anti-incumbency happened

\begin{tabular}{|c|c|}
\hline BJP won in $\mathbf{2 0 1 7}$ & INC won in 2017 \\
\hline 3 & 3 \\
\hline
\end{tabular}

Source: Same as in table-2(a)

In Jetpur, Nandod and Nizar constituencies, the average victory margin of the INC candidates against the nearest BJP rival was 10,836.7 votes (but lesser than the average victory margin of INC candidates who won viz. 15557.7 votes), and the average vote share of INC candidates in those seats was 48.7 percent (but lesser than the average vote share of winning INC candidate viz. 50.4 percent).

Out of the total 27 candidates who won in 2017 from the ST reserved constituencies, there were 14 such candidates who had won from the same constituencies in 2012 too, viz. around 51.85 
percent of winners in 2017 (irrespective of their political affiliations) had won in the previous assembly elections.

\section{Female candidates}

In 2012, 4 female candidates from BJP fought elections in the ST constituencies but all were defeated viz. namely Nilaben Hashmukhbhai Madiya in Bhiloda, Sumitraben Batukbhai Chaudhari in Dharampur, Mohindraben Ajitsinh Rathod in Garbada and Hemlataben Maheshbhai Vasava in Mandvi. However, out of 3 female candidates from INC, 2 could win viz. Chandrikaben Chhaganbhai Bariya in Garbada and Savitaben Vechatbhai Khant in Morva Hadaf.

Table 2(d): Performance of female candidates of INC and BJP in the ST reserved seats

\begin{tabular}{|c|c|c|c|c|c|c|c|}
\hline \multicolumn{4}{|c|}{2012} & \multicolumn{4}{|c|}{2017} \\
\hline $\begin{array}{l}\text { Total no. of } \\
\text { female BJP } \\
\text { candidates }\end{array}$ & $\begin{array}{c}\text { Total no. } \\
\text { of female } \\
\text { BJP } \\
\text { candidate } \\
\text { who won }\end{array}$ & $\begin{array}{l}\text { Total no. } \\
\text { of female } \\
\text { INC } \\
\text { candidate } \\
\quad \text { s }\end{array}$ & $\begin{array}{c}\text { Total no. } \\
\text { of female } \\
\text { INC } \\
\text { candidate } \\
\text { who won }\end{array}$ & $\begin{array}{l}\text { Total no. of } \\
\text { female BJP } \\
\text { candidates }\end{array}$ & $\begin{array}{c}\text { Total } \\
\text { no. of } \\
\text { female } \\
\text { BJP } \\
\text { candidat } \\
\text { e who } \\
\text { won }\end{array}$ & $\begin{array}{l}\text { Total no. } \\
\text { of female } \\
\text { INC } \\
\text { candidate } \\
\quad \text { S }\end{array}$ & $\begin{array}{c}\text { Total } \\
\text { no. of } \\
\text { female } \\
\text { INC } \\
\text { candidat } \\
\text { e who } \\
\text { won }\end{array}$ \\
\hline 4 & 0 & 3 & 2 & 1 & 0 & 1 & 1 \\
\hline
\end{tabular}

Source: Same as in table-2(a)

In 2017, only 1 female candidate from BJP (viz. Ramilaben Bara) fought election in the ST constituency of Khedbrahma but she was defeated by INC's Ashvinbhai Laxmanbhai Kotwal. From INC, only one female candidate fought and won the election viz. Chandrikaben Chhaganbhai Bariya in Garbada.

\section{Age of candidates in ST seats}

Out of the 10 BJP candidates who won from ST reserved seats in 2012, three belonged to the age bracket 20 to 40 years; six belonged to the age bracket 41 to 60 years; and just one was aged above 60 years. Among the defeated BJP candidates in that year, three were aged between 20 and 40 years (including the one who was a second runner-up in Jhagadiya viz. Narendrabhai Gambhirsinh Vasava); ten were aged between 41 and 60 years; and four were aged above 60 years.

Out of the 16 INC candidates who won from ST reserved seats in 2012, thirteen belonged to the age category 41 to 60 years and three were aged above 60 years. There was no winning candidate of INC within the age cohort 20 to 40 years. Among the defeated INC candidates in that year, two were aged between 20 and 40 years; six were aged between 41 and 60 years; and three were aged above 60 years. Please consult table-2(e). 
Table 2(e): Performance of BJP and INC candidates as per age in the ST reserved constituencies

\begin{tabular}{|c|c|c|c|}
\hline \multicolumn{2}{|c|}{2012} & \multicolumn{2}{|c|}{2017} \\
\hline $\begin{array}{l}\text { No. of winning BJP } \\
\text { candidates as per age }\end{array}$ & $\begin{array}{l}\text { No. of winning INC } \\
\text { candidates as per age }\end{array}$ & $\begin{array}{c}\text { No. of winning BJP } \\
\text { candidates as per } \\
\text { age }^{*}\end{array}$ & $\begin{array}{c}\text { No. of winning INC } \\
\text { candidates as per } \\
\text { age }^{*}\end{array}$ \\
\hline $20-40$ years $=3$ & $20-40$ years $=0$ & $20-40$ years $=1$ & $20-40$ years $=2$ \\
\hline $41-60$ years $=6$ & $41-60$ years $=13$ & $41-60$ years $=6$ & $41-60$ years $=9$ \\
\hline Above 60 years $=1$ & Above 60 years $=3$ & Above 60 years $=2$ & Above 60 years $=4$ \\
\hline $\begin{array}{c}\text { No. of losing BJP } \\
\text { candidates as per age }\end{array}$ & $\begin{array}{c}\text { No. of losing INC } \\
\text { candidates as per age }\end{array}$ & $\begin{array}{c}\text { No. of losing BJP } \\
\text { candidates as per } \\
\text { age* }^{*} \\
\end{array}$ & $\begin{array}{c}\text { No. of losing INC } \\
\text { candidates as per } \\
\text { age* }\end{array}$ \\
\hline $20-40$ years $=2+1$ (in & & & \\
\hline Jhagadiya) & $20-40$ years $=2$ & $20-40$ years $=1$ & $20-40$ years $=1$ \\
\hline $41-60$ years $=10$ & $41-60$ years $=6$ & $41-60$ years $=14$ & $41-60$ years $=6$ \\
\hline Above 60 years $=4$ & Above 60 years $=3$ & Above 60 years $=3$ & Above 60 years $=2$ \\
\hline
\end{tabular}

Source: Same as in table-2(a)

* Data pertaining to age of the candidates in 2017 assembly polls has been taken from https://eci.nic.in/eci_mainl/statistical_reportGJ.aspx (accessed in November, 2018)

Rameshbhai Bhurabhai Katara (age: 37 years) of BJP became the youngest candidate to have won a ST reserved assembly seat (viz. Fatepura) in 2012. He won against INC's Machhar Ditabhai Bhimabhai (age: 70 years).

INC's Mohansinh Chhotubhai Rathwa (Chhota Udaipur) and BJP's Mangubhai Chhaganbhai Patel (Gandevi), both aged 68 years, became the oldest candidates to have won from ST reserved constituencies in 2012.

Out of the 9 BJP candidates who won from ST reserved seats in 2017, only one was in the age category 20 to 40 years; six came in the age bracket 41 to 60 years; and two were aged above 60 years. Among the defeated BJP candidates in 2017, just one was aged between 20 and 40 years; fourteen were aged between 41 and 60 years; and three were aged above 60 years.

Out of the 15 INC candidates who won from ST reserved seats in 2017, two belonged to the age category 20 to 40 years; nine came in the age category 41 to 60 years and four were aged above 60 years. Among the defeated INC candidates in that year, only one was aged between 20 and 40 years; six were aged between 41 and 60 years; and two were aged above 60 years. 
Bhaveshbhai Babubhai Katara (age: 32 years) of INC became the youngest candidate to have won a ST reserved assembly seat (viz. Jhalod) in 2017. He won against BJP's Maheshbhai Somjibhai Bhuriya (age: 47 years).

INC's Mohansinh Chhotubhai Rathwa (Chhota Udaipur) and Premsinhbhai Devjibhai Vasava (Nandod) and BTP's Chhotubhai Amarsinh Vasava (Jhagadiya), all aged 72 years, became the oldest candidates to have won from ST reserved constituencies in 2017.

\section{Chances of winning and INC's strategy in SC seats}

Let us now turn our attention to the performance of INC and BJP in the SC reserved constituencies. The $13 \mathrm{SC}$ reserved constituencies, which have been studied pertaining to 2012 and 2017 assembly polls, are: Asarwa (Ahmedabad), Bardoli (Surat), Danilimda (Ahmedabad), Dasada (Surendranagar), Gadhada (Bhavnagar), Gandhidham (Kachchh), Idar (Sabarkantha), Kadi (Mehsana), Kalavad (Jamnagar), Kodinar (Gir Somnath), Rajkot Rural (Rajkot), Vadgam (Banaskantha) and Vadodara City (Vadodara).

In 2012, the INC contested from 13 such constituencies but won in only 3 seats, whereas in the latest assembly polls it won 5 seats while contesting from 12 constituencies. It means that the probability of winning in SC constituencies was 23.1 percent for the INC in 2012, which went up to 41.7 percent in 2017. Please consult table-3(a) for further details.

Table 3(a): Performance of BJP and INC in the 13 SC reserved constituencies during 2012 and 2017 Gujarat assembly elections

\begin{tabular}{|c|c|c|c|c|c|c|c|}
\hline \multicolumn{4}{|c|}{2012} & \multicolumn{4}{|c|}{2017} \\
\hline \multicolumn{2}{|c|}{$\begin{array}{c}\text { Number of seats } \\
\text { contested }\end{array}$} & \multicolumn{2}{|c|}{ Number of seats won } & \multicolumn{2}{|c|}{$\begin{array}{c}\text { Number of seats } \\
\text { contested }\end{array}$} & \multicolumn{2}{|c|}{ Number of seats won } \\
\hline BJP & INC & $\mathrm{BJP}$ & INC & BJP & INC & BJP & INC \\
\hline 13 & 13 & 10 & 3 & 13 & 12 & 7 & 5 \\
\hline
\end{tabular}

Source: Same as in table-2(a)

On the contrary, the probability of winning for the BJP in the SC constituencies in 2012 was 76.9 percent, which fell to 53.8 percent in 2017. Please consult table-2 for further details.

After the Una incident in July 2016, when dalit (SC) youths were beaten up by gaurakshaks (self-proclaimed cow protectors) for skinning a dead cow, a Dalit Asmita Yatra was held in August, 2016 from Ahmedabad to Una under the leadership of lawyer-activist Jignesh Mevani. ${ }^{11}$ Its objective was to protest against caste atrocities on dalits. Seeing the potential in Mevani as a dalit leader who could challenge the ruling BJP in Gujarat, the INC did not field any candidate

11 Kapoor, Shuchi (2016): When Dalits threw away cow carcasses and upended hierarchies in Gujarat, The Economic Times, 21 August, https://goo.gl/NReTib 
from the Vadgam seat in 2017. Instead the party cooperated with Mevani who stood from that seat as an independent candidate and won by a margin of 19,696 against his nearest rival Vijaykumar Harkhabhai Chakravarti of BJP. The sitting INC MLA Manilal Jethabhai Vaghela did not contest from Vadgam in 2017. The Aam Aadmi Party (AAP) also extended its support to Jignesh Mevani. ${ }^{12}$

\section{Vote share and victory margins in SC constituencies}

On an average, a winning candidate belonging to INC got a vote share of 51.5 percent in 2012, which increased to 53.8 percent in the last assembly polls in Gujarat. On the other hand, a victorious candidate from BJP got an average vote share of 49.9 percent in 2012, which went up to 55.3 percent in 2017. Please check table-3(b) for further details.

A successful BJP candidate won by an average margin of 18,769.5 votes against its nearest rival in 2012, but this margin jumped to $25,929.9$ in 2017. On the other hand, a victorious INC candidate on an average won by margin of 12,452.3 votes against the runner-up in 2012 but this margin climbed to $18,629.6$ votes in 2017 .

Table 3(b): Performance of BJP and INC candidates in terms of vote share and victory margin in the $\mathrm{SC}$ reserved seats

\begin{tabular}{|c|c|c|c|c|c|c|c|}
\hline & & & & & & & \\
\hline $\begin{array}{l}\text { Average } \\
\text { winning }\end{array}$ & $\begin{array}{l}\text { share of } \\
\text { adidates }\end{array}$ & $\begin{array}{r}\text { Avera } \\
\text { of } r \\
\text { ca }\end{array}$ & $\begin{array}{l}\text { share } \\
\text {-up } \\
\text { tes }\end{array}$ & $\begin{array}{r}\text { Average } \\
\text { of } w \\
\text { cant }\end{array}$ & $\begin{array}{l}\text { te share } \\
\text { ning } \\
\text { ates }\end{array}$ & $\begin{array}{r}\text { Avera } \\
\text { of } r \\
\text { ca }\end{array}$ & $\begin{array}{l}\text { share } \\
\text {-up } \\
\text { tes }\end{array}$ \\
\hline BJP & INC & BJP & INC & BJP & INC & BJP & INC \\
\hline 49.9 & 51.5 & 43.5 & 37 & 55.3 & 53.8 & 40.6 & 39.2 \\
\hline $\begin{array}{r}\text { Avera } \\
\text { margin } \\
\text { can }\end{array}$ & $\begin{array}{l}\text { ictory } \\
\text { vinning } \\
\text { ate }\end{array}$ & $\begin{array}{r}\mathrm{Nu} \\
\text { constitı } \\
\text { candid } \\
\text { marg } \\
\mathbf{3 0 0 0}\end{array}$ & $\begin{array}{l}\text { of } \\
\text { s where } \\
\text { n by a } \\
\text { or = } \\
\text { votes }\end{array}$ & $\begin{array}{c}\text { Averag } \\
\text { margin } \\
\text { can }\end{array}$ & $\begin{array}{l}\text { victory } \\
\text { winning } \\
\text { late }\end{array}$ & $\begin{array}{r}\mathrm{Nu} \\
\text { constitı } \\
\text { candid } \\
\text { marg } \\
\mathbf{3 0 0 0}\end{array}$ & $\begin{array}{l}\text { of } \\
\text { s where } \\
\text { on by a } \\
\text { or = } \\
\text { votes }\end{array}$ \\
\hline $\begin{array}{c}\text { BJP } \\
\text { (C.V.) }\end{array}$ & $\begin{array}{c}\text { INC } \\
\text { (C.V.) }\end{array}$ & BJP & INC & $\begin{array}{c}\text { BJP } \\
\text { (C.V.) }\end{array}$ & $\begin{array}{c}\text { INC } \\
\text { (C.V.) }\end{array}$ & BJP & INC \\
\hline $\begin{array}{l}18769.5 \\
(77.7 \%)\end{array}$ & $\begin{array}{l}12452.3 \\
(83.8 \%)\end{array}$ & 0 & 1 & $\begin{array}{l}25929.9 \\
(76.7 \%)\end{array}$ & $\begin{array}{l}18629.6 \\
(72.1 \%)\end{array}$ & 1 & 0 \\
\hline
\end{tabular}

Note: $C . V$. stands for coefficient of variation, which is the ratio of the standard deviation to arithmetic mean multiplied by 100

Source: Same as in table-2(a)

\footnotetext{
12 Jignesh Mevani to contest as Independent with Congress' support, The Hindu, 27 November, 2017, https://goo.gl/2Ap4dA
} 
The volatility or variability in the victory margin (as measured by coefficient of variation) of INC candidates has waned from 83.8 percent to 72.1 percent between 2012 and 2017 . However, the volatility in the victory margin of BJP candidates has fallen marginally from 77.7 percent to 76.7 percent between the last two assembly elections.

In 2012, only one candidate from the INC won by a margin of less than or equal to 3,000 votes against the runner-up, whereas in 2017 only one candidate from the BJP won by a margin of less than or equal to 3,000 votes against the nearest rival.

In 2012, Rameshbhai Maganbhai Chavada of INC defeated Hitu Kanodiya of BJP by a margin of 1,217 votes in the Kadi assembly seat of Mehsana district. In 2017, Lakhabhai Sagathiya of BJP defeated Vashrambhai Alabhai Sagathiya of INC by a margin of 2,179 votes in the Rajkot Rural assembly seat of Rajkot district. It should be added here that in 2012, Lakhabhai Sagathiya fought with a INC ticket against BJP's Bhanuben Manoharbhai Babariya but was defeated by the latter by a margin of 11,466 votes.

\section{Anti-incumbency factor in SC seats}

Due to anti-incumbency factor, INC won in 4 SC reserved seats in 2017, which were earlier occupied by BJP viz. Dasada, Gadhada, Kalavad and Kodinagar. In these 4 constituencies, the average victory margin of the INC candidates against the nearest BJP rival was $15,159.5$ votes (but lesser than the average victory margin of winning INC candidate viz. 18,629.6 votes), and the average vote share of INC candidates in these seats was 52.7 percent (but less than the average vote share of winning INC candidate viz. 53.8 percent). Please refer to table-3(c) for further details.

Table 3(c): Number of SC reserved constituencies where anti-incumbency happened

\begin{tabular}{|c|c|}
\hline BJP won in 2017 & INC won in 2017 \\
\hline 1 & 4 \\
\hline
\end{tabular}

Source: Same as in table-2(a)

The BJP, on the other hand, was able to snatch just 1 SC reserved seat from the INC in 2017 due to anti-incumbency factor viz. Kadi seat of Mehsana district. The sitting INC MLA Rameshbhai Maganbhai Chavada was defeated by Karshanbhai Punjabhai Solanki of BJP by 7,746 votes.

Out of the total 13 candidates who won in 2017 from the SC reserved constituencies, there were 3 such candidates who had won from the same constituencies in 2012 also, viz. nearly 23.08 percent of winners in 2017 (having the same political affiliation) had won in the previous assembly election too. 


\section{Female candidates}

In 2012, two female candidates of BJP namely Bhanuben Manoharbhai Babariya and Manisha Rajivbhai Vakil contested elections in the SC constituencies of Rajkot Rural and Vadodara City, respectively, and both of them won. Both the two female candidates from INC namely Jayshreeben Ajitbhai Chavada and Jayshreeben Ashvinbhai Solanki were defeated in the constituencies of Gandhidham and Vadodara City, respectively.

Table 3(d): Performance of female candidates of INC and BJP in the SC reserved seats

\begin{tabular}{|c|c|c|c|c|c|c|c|}
\hline \multicolumn{4}{|c|}{ Performance of female candidates in 2012} & \multicolumn{4}{|c|}{ Performance of female candidates in 2017} \\
\hline $\begin{array}{c}\text { Total no. } \\
\text { of female } \\
\text { BJP } \\
\text { candidates }\end{array}$ & $\begin{array}{c}\text { Total no. } \\
\text { of female } \\
\text { BJP } \\
\text { candidate } \\
\text { who won }\end{array}$ & $\begin{array}{c}\text { Total no. } \\
\text { of female } \\
\text { INC } \\
\text { candidates }\end{array}$ & $\begin{array}{c}\text { Total no. } \\
\text { of female } \\
\text { INC } \\
\text { candidate } \\
\text { who won }\end{array}$ & $\begin{array}{c}\text { Total no. } \\
\text { of female } \\
\text { BJP } \\
\text { candidate } \\
\text { s }\end{array}$ & $\begin{array}{c}\text { Total no. } \\
\text { of female } \\
\text { BJP } \\
\text { candidate } \\
\text { who won }\end{array}$ & $\begin{array}{l}\text { Total no. } \\
\text { of female } \\
\text { INC } \\
\text { candidate } \\
\text { s }\end{array}$ & $\begin{array}{l}\text { Total no. } \\
\text { of female } \\
\text { INC } \\
\text { candidate } \\
\text { who won }\end{array}$ \\
\hline 2 & 2 & 2 & 0 & 2 & 2 & 0 & 0 \\
\hline
\end{tabular}

Source: Same as in table-2(a)

In 2017, two female candidates of BJP namely Maheshwari Malti Kishor and Manisha Vakil contested elections in the SC constituencies of Gandhidham and Vadodara City, respectively, and both of them won. No female candidate was fielded by INC in any SC constituency in that year.

\section{Age of candidates in SC seats}

Out of the 10 BJP candidates who won from SC reserved seats in 2012, two came in the age cohort 20 to 40 years and eight belonged to the age bracket 41 to 60 years. Among the defeated BJP candidates in that year, two were aged between 41 and 60 years and just one was aged above 60 years. Please check table-3(e). 
Table 3(e): Performance of BJP and INC candidates as per age in the SC reserved constituencies

\begin{tabular}{|c|c|c|c|}
\hline \multicolumn{2}{|c|}{2012} & \multicolumn{2}{|c|}{2017} \\
\hline $\begin{array}{l}\text { No. of winning BJP } \\
\text { candidates as per age }\end{array}$ & $\begin{array}{l}\text { No. of winning INC } \\
\text { candidates as per age }\end{array}$ & $\begin{array}{c}\text { No. of winning BJP } \\
\text { candidates as per } \\
\text { age* }^{\text {age }} \\
\end{array}$ & $\begin{array}{c}\text { No. of winning INC } \\
\text { candidates as per } \\
\text { age }^{*}\end{array}$ \\
\hline $\begin{array}{c}20-40 \text { years }=2 \\
41-60 \text { years }=8 \\
\text { Above } 60 \text { years }=0\end{array}$ & $\begin{array}{c}20-40 \text { years }=0 \\
41-60 \text { years }=3 \\
\text { Above } 60 \text { years }=0\end{array}$ & $\begin{array}{c}20-40 \text { years }=1 \\
41-60 \text { years }=6 \\
\text { Above } 60 \text { years }=0\end{array}$ & $\begin{array}{c}20-40 \text { years }=0 \\
41-60 \text { years }=5 \\
\text { Above } 60 \text { years }=0\end{array}$ \\
\hline $\begin{array}{c}\text { No. of losing BJP } \\
\text { candidates as per age }\end{array}$ & $\begin{array}{l}\text { No. of losing INC } \\
\text { candidates as per age }\end{array}$ & $\begin{array}{l}\text { No. of losing BJP } \\
\text { candidates as per } \\
\qquad \text { age }^{*}\end{array}$ & $\begin{array}{l}\text { No. of losing INC } \\
\text { candidates as per } \\
\text { age* }\end{array}$ \\
\hline $\begin{array}{c}20-40 \text { years }=0 \\
41-60 \text { years }=2 \\
\text { Above } 60 \text { years }=1\end{array}$ & $\begin{array}{c}20-40 \text { years }=1 \\
41-60 \text { years }=8 \\
\text { Above } 60 \text { years }=1\end{array}$ & $\begin{array}{c}20-40 \text { years }=0 \\
41-60 \text { years }=6 \\
\text { Above } 60 \text { years }=0\end{array}$ & $\begin{array}{c}20-40 \text { years }=1 \\
41-60 \text { years }=4 \\
\text { Above } 60 \text { years }=2\end{array}$ \\
\hline
\end{tabular}

Source: Same as in table-2(a)

* Data pertaining to age of the candidates in 2017 assembly polls has been taken from https://eci.nic.in/eci_mainl/statistical_reportGJ.aspx (accessed in November, 2018)

All the three INC candidates who won from SC reserved seats in 2012 belonged to the age category 41 to 60 years. Among the defeated INC candidates in that year, just one was aged between 20 and 40 years; eight were aged between 41 and 60 years; and only one was aged above 60 years.

BJP's Bhanuben Manoharbhai Babariya (Rajkot Rural) and Manisha Rajivbhai Vakil (Vadodara City), both aged 37 years, became the youngest candidates to have won from SC reserved constituencies in 2012.

Ramanlal Ishvarlal Vora (age: 60 years) of BJP became the oldest candidate to have won a SC reserved assembly seat (viz. Idar) in 2012. He won against INC's Ramabhai Virchandbhai Solanki (age: 41 years).

Out of the 7 BJP candidates who won from SC reserved seats in 2017, just one candidate belonged to the age group 20 to 40 years and the rest 6 belonged to the age bracket 41 to 60 years. Among the defeated BJP candidates in that year, all six were aged between 41 and 60 years. 
All the five INC candidates who won from SC reserved seats in 2017 belonged to the age category 41 to 60 years. Among the defeated INC candidates in that year, just one was aged between 20 and 40 years; four were aged between 41 and 60 years; and two were aged above 60 years.

BJP's Maheshwari Malti Kishor (Gandhidham), aged 28 years, became the youngest candidate to have won from SC reserved constituency in 2017. She defeated INC's Kishor Gangjibhai Pingol (aged 37 years). A news report of The Times of India (dated 18 December, 2017) says that Maheshwari Malti Kishor's uncle Maheshwari Ramesh Vachchhraj of BJP was the sitting MLA from Gandhidham who defeated INC's Jayshreeben Ajitbhai Chavada in 2012. ${ }^{13}$

Karshanbhai Punjabhai Solanki (age: 60 years) of BJP became the oldest candidate to have won a SC reserved assembly seat (viz. Kadi) in 2017. He won against INC's Rameshbhai Maganbhai Chavda (age: 66 years).

\section{Concluding remarks}

The analysis of past trends shows that the vote share of BJP in various assembly elections of Gujarat increased from 1990 onwards and has remained close to around 49 percent since 2002. However, for the first time since 1995 the total number of seats won by BJP in different assembly elections of Gujarat came down below 100 in 2017 (i.e., 99 seats).

INC's vote share in various assembly elections of Gujarat went up gradually since 1990 and reached almost 43 percent in 2017. The total number of seats won by INC in different assembly elections of Gujarat has more than doubled from 33 in 1990 to 77 in 2017.

The number of seats won as a proportion of seats contested was greater than 60 percent for the BJP in the assembly polls of 1995, 1998, 2002, 2007 and 2012. In fact, BJP's chances of winning a particular seat reached its peak in 2002 (viz. 69.8 percent). On the contrary, the number of seats won as a proportion of seats contested crossed 40 percent for INC (viz. 43.5 percent) for the first time in the assembly polls of 2017.

During the past 7 assembly elections since 1990, the total number of seats won by INC in the ST reserved constituencies surpassed the total number of seats won by BJP, except in the years 1995 and 2002.

It would be too early to say that BJP's anti-Muslim propaganda and communal agenda is yielding diminishing returns in the ST reserved seats. Why so? It is because the vote share of victorious BJP candidates has risen from 47.9 percent to 53.6 percent between 2012 and 2017 in the ST reserved constituencies. On the contrary, the vote share of victorious INC candidates has declined from 51.5 percent to 50.4 percent between 2012 and 2017. Having said that, it should be added here that INC's pre-poll alliance with BTP helped it to increase its overall number of seats to 17 in 2017 from 16 in 2012 in those constituencies.

\footnotetext{
${ }^{13}$ Gujarat Minority Seats: Congress leading in ST seats; BJP ahead in OBC, SC constituencies, The Times of India, 18 December, 2017, https://goo.gl/KwNYQ4
} 
The total number of seats won by INC during assembly elections in the SC seats was always lesser than the total number of seats won by BJP since 1990. However, during the 2017 assembly polls, BJP (7) was marginally ahead of INC (5) in terms of winning SC reserved seats. The average vote share of both INC's (51.5 percent in 2012; 53.8 percent in 2017) and BJP's (49.9 percent in 2012; 55.3 percent in 2017) victorious candidates went up between 2012 and 2017. If we take into account the victory by the independent candidate Jigneshkumar Natvarlal Mevani in Vadgam, then the overall number of seats won by INC has doubled to 6 in 2017 from 3 in 2012 in the SC constituencies.

In the reserved constituencies $(\mathrm{SC}+\mathrm{ST})$, the total number of seats won by INC on its sole power has increased from 19 in 2012 to 20 in 2017 and the total number of seats won by BJP fell from 20 to 16 during the same span.

On certain parameters, however, the performance of BJP and INC show mixed results. My data analysis shows that the average vote share of a winning candidate of BJP increased in both the SC and ST constituencies between the two timepoints. While the average vote share of a winning candidate from INC increased in SC constituencies, it fell in the ST constituencies.

Although the probability of winning by an INC candidate has increased in both SC and ST constituencies between 2012 and 2017, the average victory margin secured by a winning candidate of INC against the nearest rival in the ST constituencies has fallen, shows this analysis. On the contrary, the average victory margin secured by a winner of INC against the nearest rival in SC constituencies has increased between the two timepoints under discussion.

The chances of winning by a BJP candidate has decreased in both SC and ST constituencies between 2012 and 2017. However, the average victory margin secured by a victorious BJP candidate against the nearest rival in both ST and SC constituencies has gone up.

Due to anti-incumbency factor, both BJP and INC gained same number of seats ( 3 each) in the ST constituencies in 2017. INC (4) gained a greater number of seats vis-à-vis the BJP (1) due to anti-incumbency factor in the SC constituencies.

No female candidate could win a single seat for BJP in the ST constituencies in both 2012 and 2017. Likewise, no female candidate could win a single seat for INC in the SC constituencies in 2012. In 2017, no female candidate from INC contested election in the SC constituencies.

\section{References:}

Banerjee, Souradeep and Dhar, Shashwat (2017): Victory sans Grandeur: Gujarat Assembly Election 2017, Economic and Political Weekly, 23 December, Vol. 52, Issue No. 51, https://goo.gl/8rqyVS (accessed on 13 March, 2018)

Deepalakshmi, K (2017): Bharatiya Tribal Party opens account in Gujarat, The Hindu, 18 December, https://goo.gl/tnmVqW 
Gujarat Minority Seats: Congress leading in ST seats; BJP ahead in OBC, SC constituencies, The Times of India, 18 December, 2017, https://goo.gl/KwNYQ4 (accessed on 13 March, 2018)

Jignesh Mevani to contest as Independent with Congress' support, The Hindu, 27 November, 2017, https://goo.gl/2Ap4dA (accessed on 13 March, 2018)

Kapoor, Shuchi (2016): When Dalits threw away cow carcasses and upended hierarchies in Gujarat, The Economic Times, 21 August, https://goo.g1/NReTib

Lokniti-CSDS-ABP News Gujarat Pre-Election Tracker, Round 3, December 4, 2017, https://goo.gl/DSfwDY

Shah, Ghanshyam (2018): A Puzzle: BJP's Sixth Victory in Gujarat, Economic and Political Weekly, 13 January, Vol. 53, Issue No. 2, https://goo.gl/bixHbp (accessed on 13 March, 2018)

Shah, Ghanshyam (2014): Chapter 11: Mega Marketing and Management: Gujarat's 2014 Elections, in the book entitled 'India's 2014 Elections: A Modi-led BJP Sweep' edited by Paul Wallace, Sage Publications

Shah, Ghanshyam (2004): Chapter 6: Gujarat after Godhra, in the book entitled 'India's 2004 Elections: Grass-roots and National Perspectives' edited by Ramashray Roy and Paul Wallace, Sage Publications

Sharma, Vinod (2017): About time Congress projected tribal faces in Gujarat -Vinod Sharma, Hindustan Times, 7 November, https://goo.gl/mXxCv3

Singh, Sanjeev (2017): Why tribal votes could spring a surprise in Gujarat elections, The Times of India blog, 28 November, https://goo.gl/vAVz8T (accessed on 13 March, 2018)

Gujarat General Legislative Election 2017, https://eci.nic.in/eci_main1/statistical_reportGJ.aspx (accessed in November, 2018)

Statistical Report on General Election - 2012 to the Legislative Assembly of Gujarat, https://bit.ly/2T9Xnwb (accessed in November, 2018)

Statistical Report on General Election - 2007 to the Legislative Assembly of Gujarat, https://bit.ly/2B2fNIw (accessed in November, 2018)

Statistical Report on General Election - 2002 to the Legislative Assembly of Gujarat, https://bit.ly/2DBIM8o (accessed in November, 2018)

Statistical Report on General Election - 1998 to the Legislative Assembly of Gujarat, https://bit.ly/2DhgUpa (accessed in November, 2018) 
Statistical Report on General Election - 1995 to the Legislative Assembly of Gujarat, https://bit.ly/2B47dZF (accessed in November, 2018)

Statistical Report on General Election - 1990 to the Legislative Assembly of Gujarat, https://bit.ly/2T7M5bW (accessed in November, 2018)

Delimitation of Parliamentary and Assembly Constituencies Order, 2008, Election Commission of India, https://bit.ly/2OMHrfY (accessed in November, 2018) 